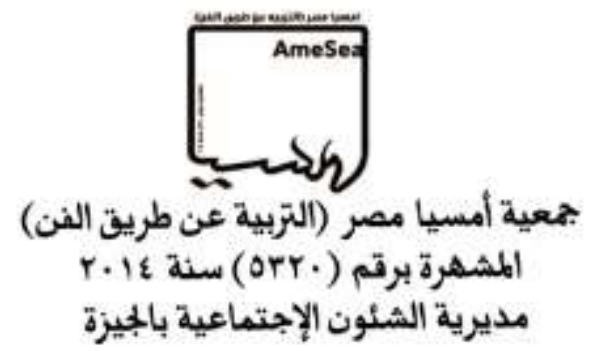

سمات الاغتراب في تصوير الفنانات العراقيات في المهجر

\title{
إعداد
}

جلال رحيم عودة 


\section{مقدمة البحث:}

حمل الفن الثصوير العر اقي بذرة التحولات الأسلويية التي تعطي طبيعة المرحلة التي يمر بها

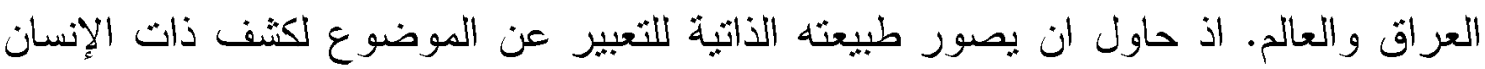

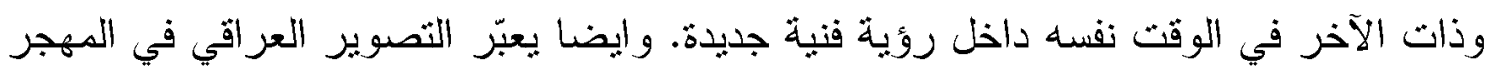

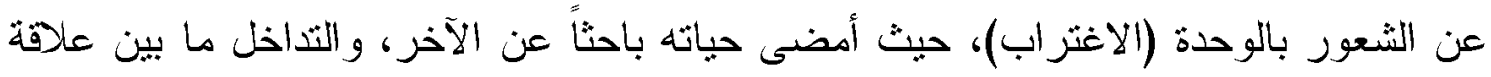

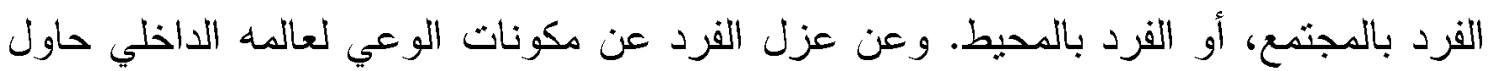
التصوير العراقي في المهجر الاحتفاظ بحيّزه الوجودي ومسؤولية منطلبات الحياة المعاثية. فتجربته لا تتفصل عن ما عانى العراق، فهو جزء من تجربته العز اقية، بل امتداد لها.

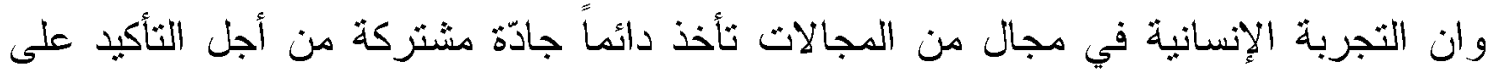

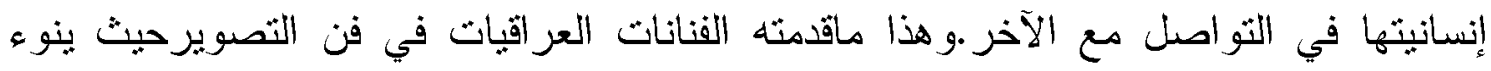

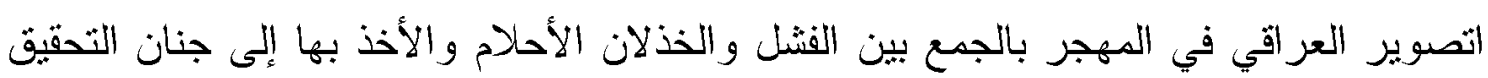

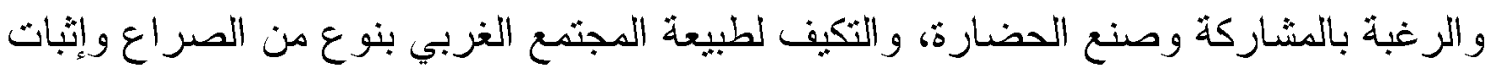

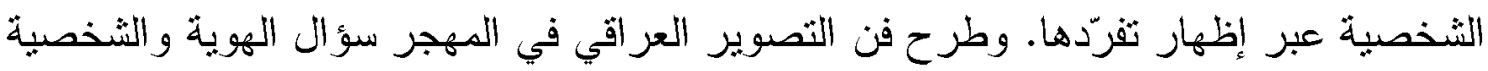

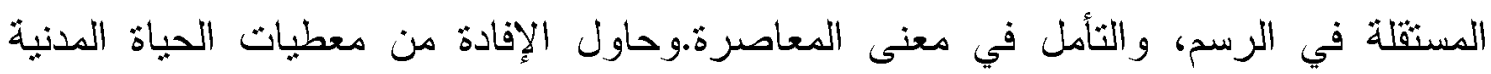
والحضارية في أوربا من تقنبات ومو اضيع وأساليب تمزج شخصيته بتلك المؤثرات.

مثكلة البحث

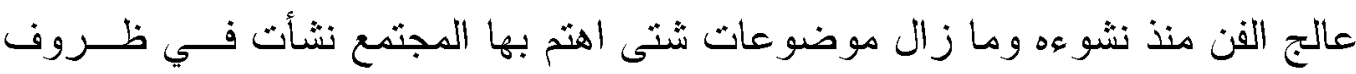

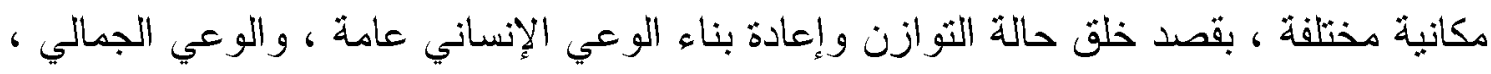

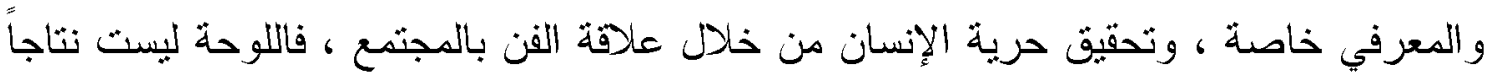
منفصلاً.

ففي العصر الحديث بدت جملة مفاهيم نظهر في ما لذلك من انعكاسات نتيجة لما عانته

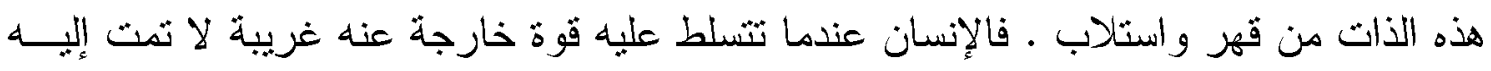

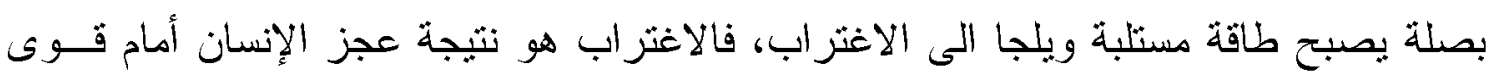

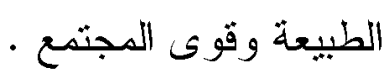

فمهوم ( الاغتراب ) أنثقل أثره من الطابع الاجتماعي والاقتصادي والسياسي والــديني

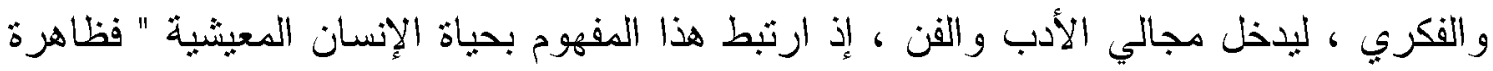

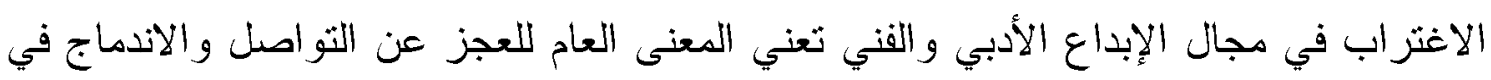


النسيج الاجتماعي ، والاعتقاد في قيمه الأساسية وتحقيق الذات في إطاره الخانق " (') ـ و المر أة

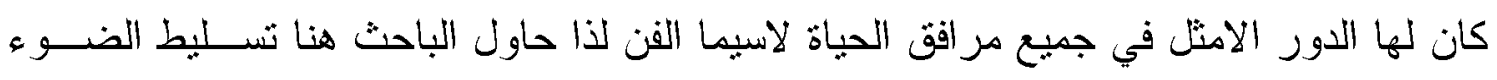

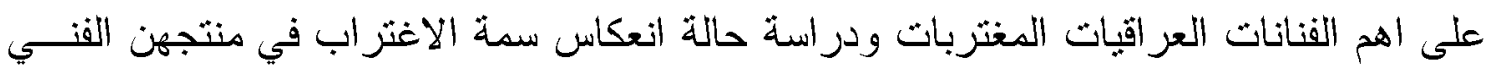
وجاء تساؤل البحث هنا : - ماهي سمات الاغتراب في تصوير الفنانات العر اقيات في المهجر أهمية البحث والحاجة إليه 1الكثنف عن مفهوم الاغنراب في الفن. r إلتعرف على اهم الفنانات العر اقيات في المهجر بـاثر اء المكتبة الفنبة بدراسة عن فن التصوير في العراق هدف البحث :

1. الكثنف عن الأنواع الاغنر ابية وتحديدها في تصوير الفنانات العر اقيات في المهجر.

\section{حدود البحث}

يتحدد البحث الحالي بدراسة سمات رسوم الفنانات العر اقبات في المهجر وعلى وفق الاتي : 1-الحدود الزمانية :من عقد الخمسينات حتى أواخر العقد التسعينات (1909-1999). r- الحدود المكانية :أوربا وأمريكا.

ب- تختص الدراسة بتحليل أعمال الفنانات العر اقيات في المهجر وهن(عفيفة لعيبـي - ســعاد

$$
\begin{aligned}
& \text { العطار - وداد الازوفلي) } \\
& \text { فرض البحث: }
\end{aligned}
$$

- هناك تأثير ناتج من أثز الهجرة على الشكل والمحتوى والتعبير الفني في تصوير الفنانات في المهجر - الماتر

- ان للاغتر اب سمات جمالية تضبفها على النتاج الفني لفنانات المهجر.

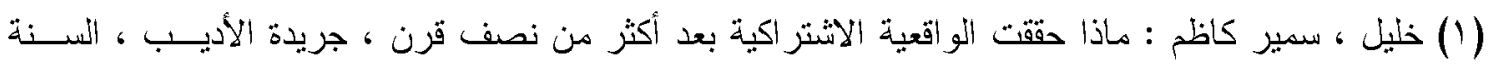

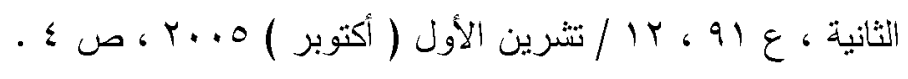




$$
\text { ا ـ الاغتر اب أ. الاغتراب لغة }
$$

وردت كلمة الاغتراب في معجم المنجد فيما بخص الابتعاد و النوى على النحو الآتـي:

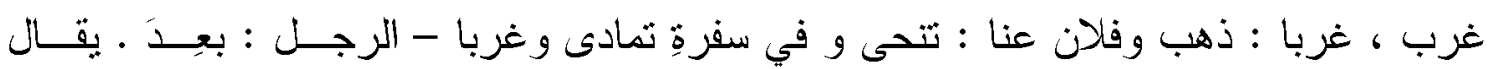

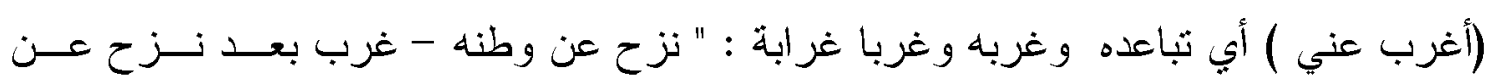

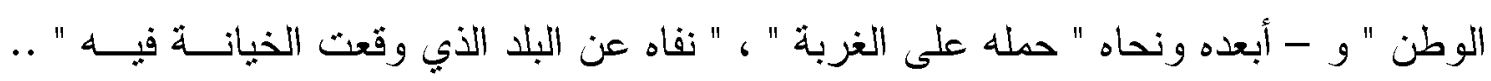

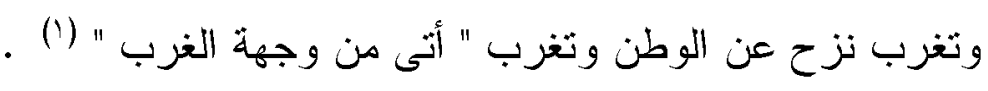
ب. ب. الاغتر اب اصطلاحاً

بعرف كرزويل الاغتراب بأنه : " حالة نفسية اجنماعية تسيطر على الفرد فتجعله غريباً

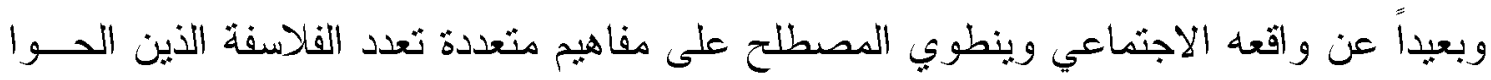

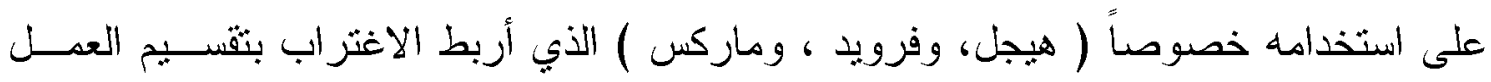

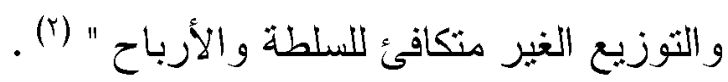
التعريف الإجرائي :

الاغتراب هو عملية انسلاخ الإنسان عن واقعه و عجزه بالارثقاء إلى ما هـــو أفضــل لتحقيق ذاته. الاطار النظري : (الن

الهجرة هي في الاساس انتقال الافراد من مواطنهم الاصلية الى أوطـــان جديــدة لعـدة

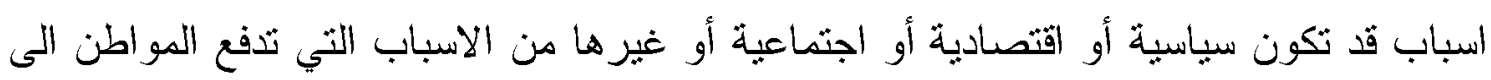

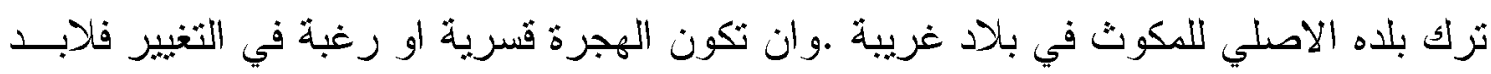

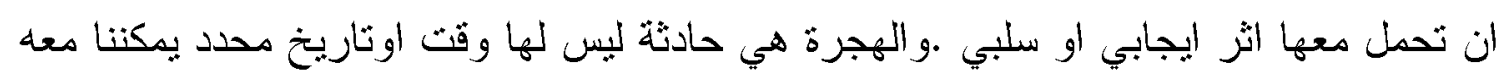

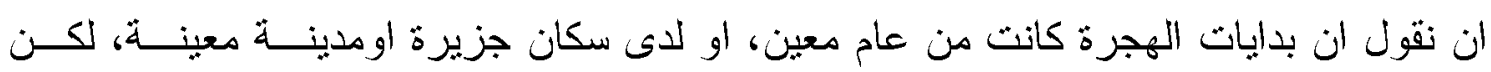

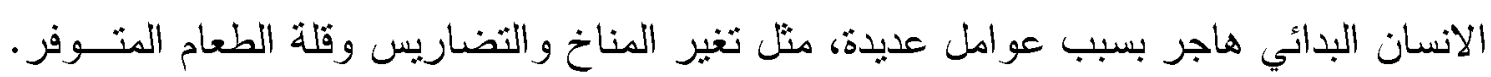

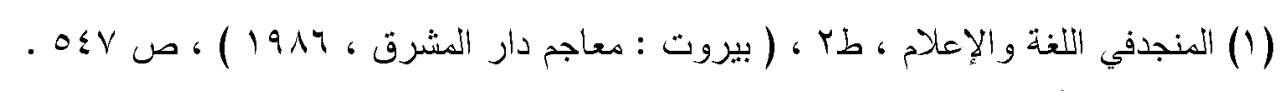

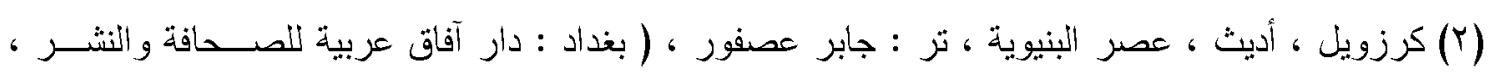
. r $4 \leqslant$ (1910 
اي من خلال ذلك يتوصل الباحث الى ان الهجرة هي دافع بالاساس وليست حادثة معينة وهـــه

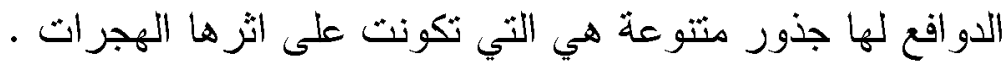

وللهجرة اسباب ودو افع ثدفع الفرد الى التخلي عن ارضه للبحث عن ارض جديدة خالية

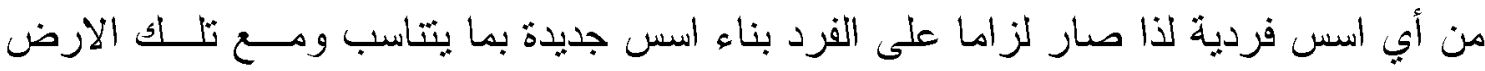

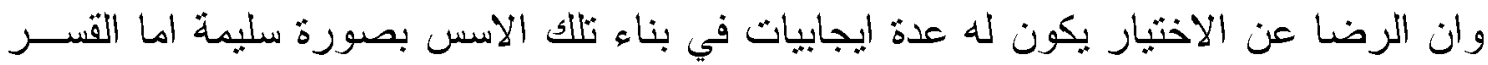
و الاجبار على الهجرة قد لا يلحقها في اغلب الاحيان اسس صائبة ان وجدت الاسس في الاصل

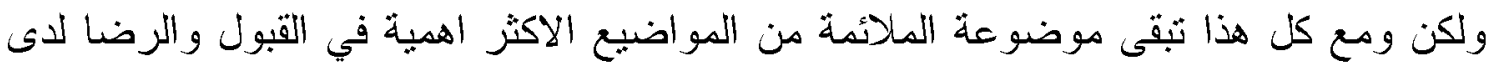

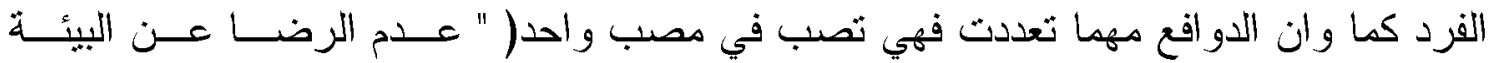

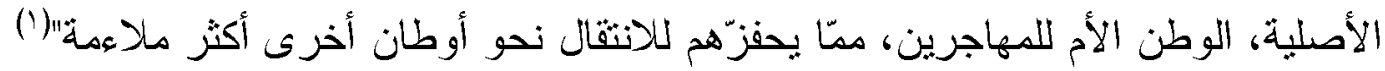

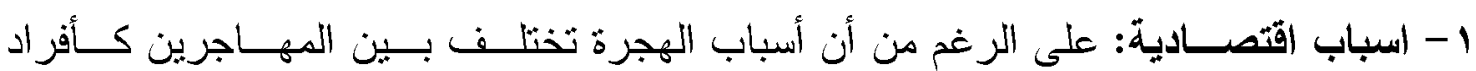

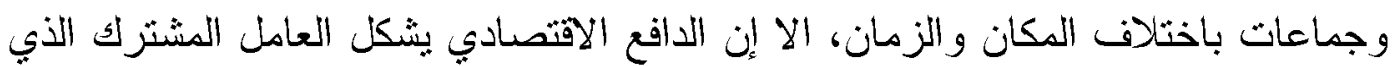

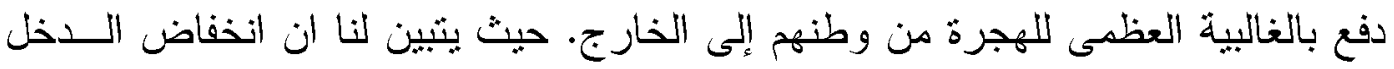

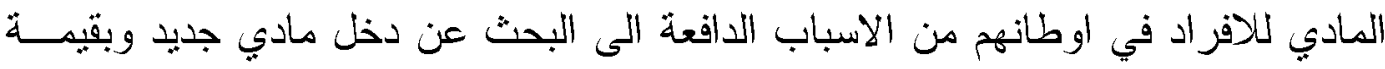

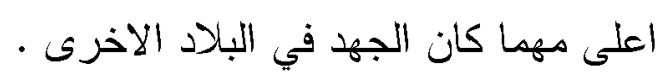

ץ- اسباب سياسية: حيث يجدون أنفسهم في تعارض مع البيئة السياسية في مجتمعاتهم فيقدمون

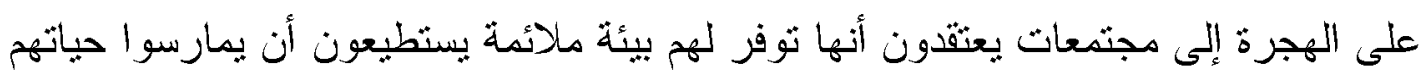

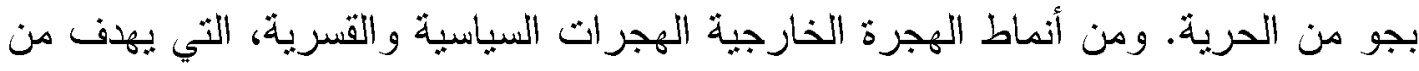

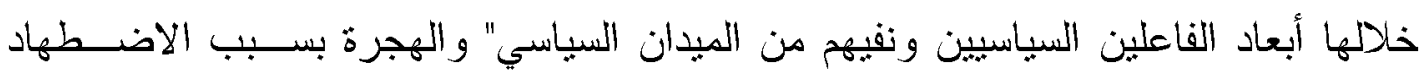

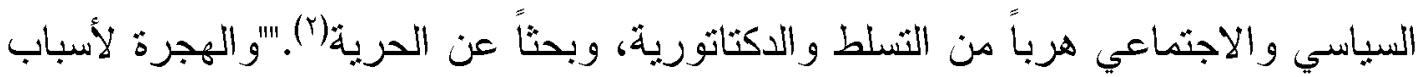
سياسية هي عادة إجبارية قسرية.

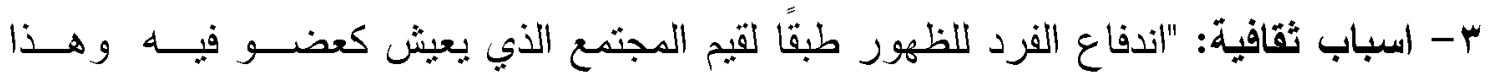

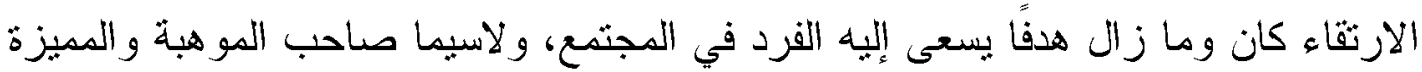

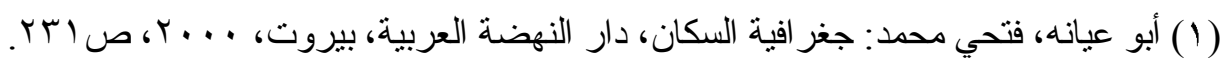

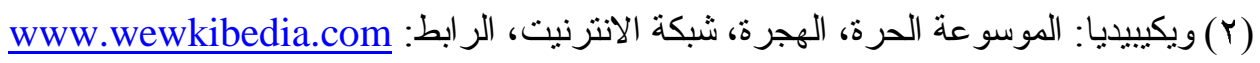


الخاصة التي لا تتو افر لدى غبره من أفزاد طبقته، الأمر الذبي يشكل محددًا وسبيًا لحراكـــه (1) المكاني (لهجرته)

ـ - اسباب اجتماعية: حبث طبيعة العو امل الاجنماعية وأسلوب وأنماط الحياة والمعيثة السائدة

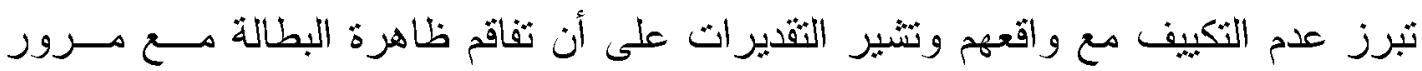
الزمن واستمر ار الفجوة بين معدلات النمو السكاني و النمو الإقتصادي سيزيد مـن عوامـلـل

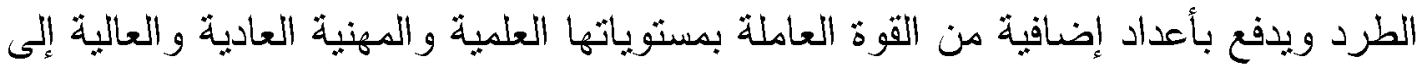

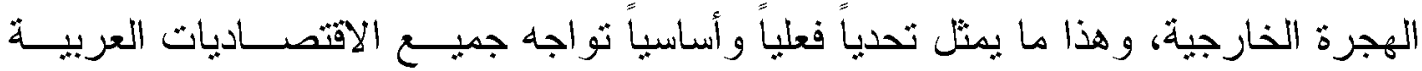

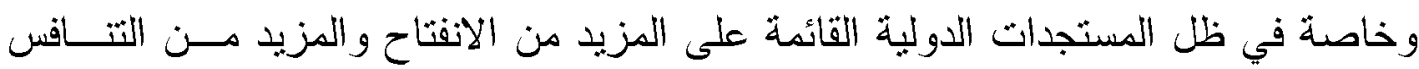

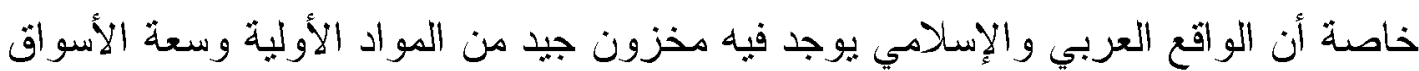

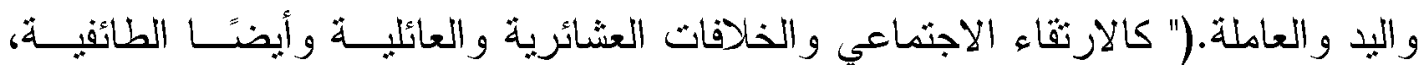

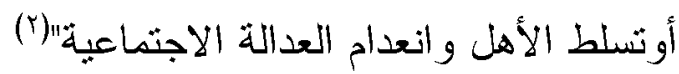

الاغتر اب في الفن : n

تعثبر ظاهرة الاغتراب ظاهرة فلسفية ونفسية اجتماعبة على حد سواء وان الاغتــراب

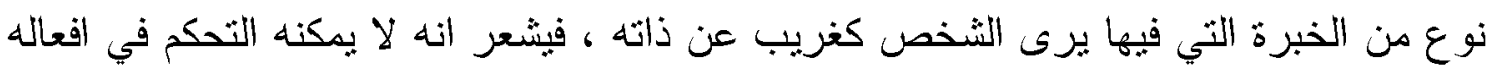
بل تسوقه افعاله وينساق ورائها مها يجعله بعيد الاتصال عن ذاته وبعيد الاتصال باي فرد اخر و انه وعي الفرد بالصر اع القائم بين ذاته و الييئة المحبطة به، و المحبطة له بصورة تثجسد فـي لهي

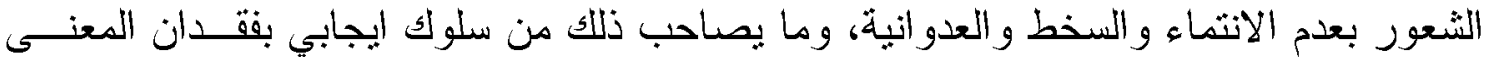

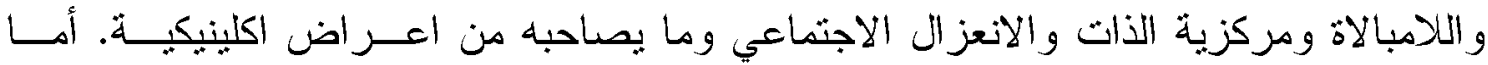
الاغتراب في المفهوم الفلسفي هو " غربة الإنسان عن جوهره ، وتتزله عن المقام الذي ينبغسي

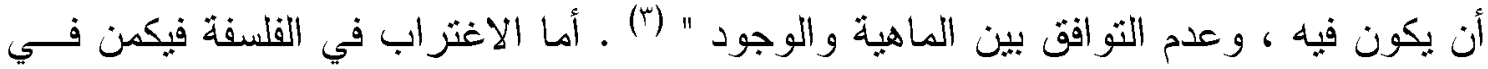
بحث الإنسان عن حقيقة وجوده ومعرفة ذاته ، فعملية البحث هذه تجعله في حالة انفصال عـن

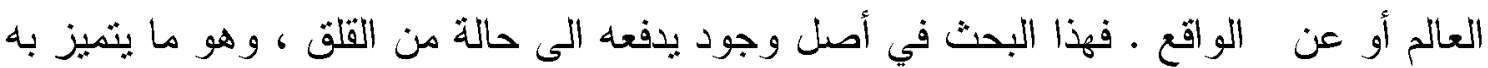
الإنسان المغترب ـ فهو يجد ان القلق ما هو إلا صفة كادنة وأصبلة في أعماق الوجود الإنساني

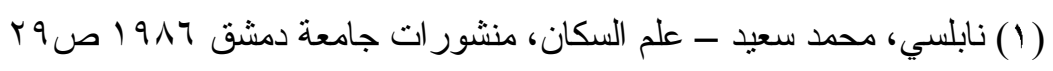

(r) د. توفيق الجرجور ، ، الهجرة من الريف إلى المدن في القطر العربي السوري، منشورات. وزارة الثقافة،

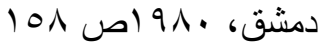

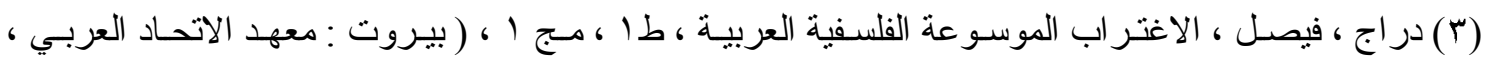
. V9 (1919 ( ) (19) 
إذ يتحول الإنسان بفعل حالة القلق من " حالة التوافق و التكامل و التتاغم مع وجود معبن الى حالة

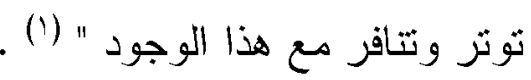
ويعتبر هيغل اول من استخدم الاغتراب، وقد كان للاغتراب معنى مزدوج، وكان يقصد

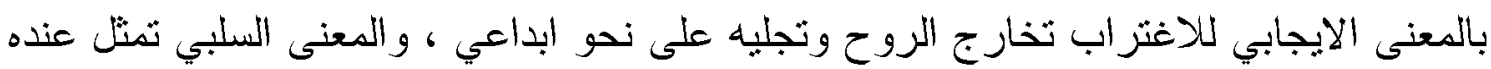

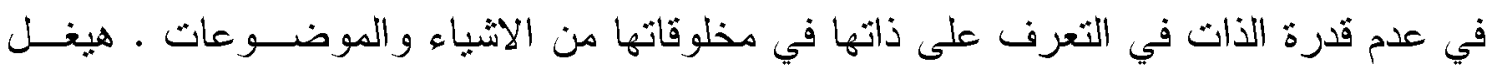

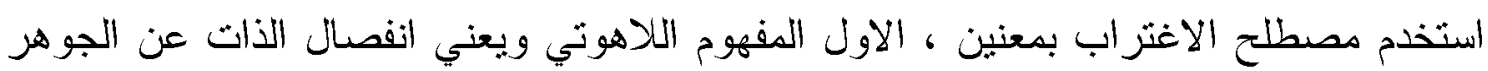

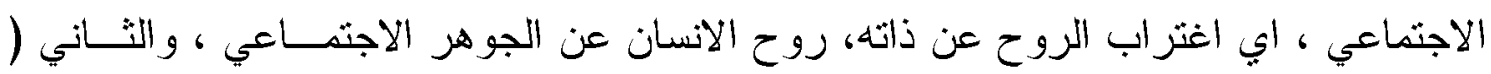

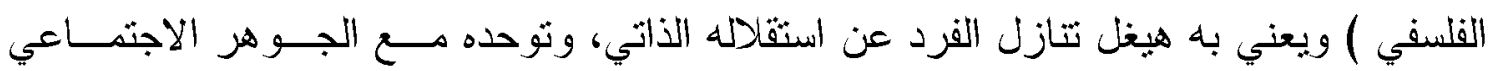

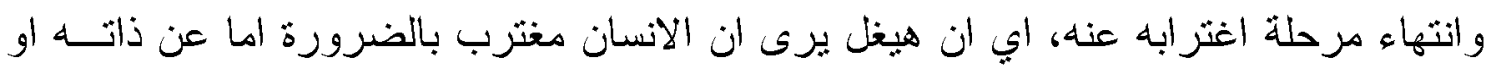

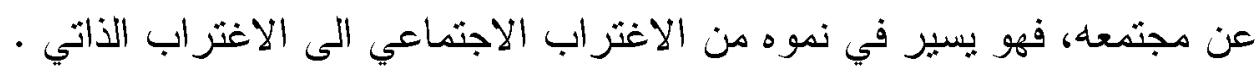

الا ان مصطلح الاغتراب قد اصبح احادي البعد حبث فقد المعنى الايجابي لــه، وبــــأ

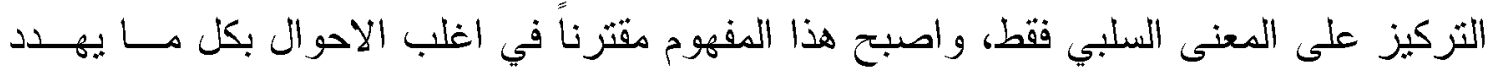
الانسان وحريثه بالاستئصال او التزييف ، هذا ما جعل الاغتر اب بمفهومه الاحادي ينتشر فئسي

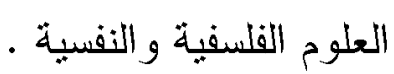

إن الإحساس بالغربة خارج الوطن لا ينوقف عند مجرد الحنين إلبه والحلم بـالعودة أو

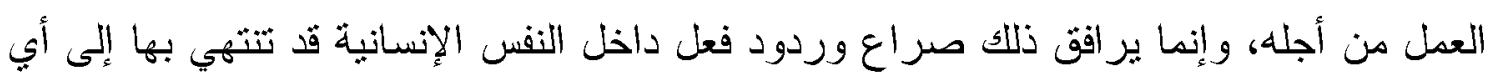
مظهز من مظاهر الاغتراب الروحي أو النفسي.

وقد انعكست هذه الظاهرة على الأدب، فغدا الاغتراب( موضوعاً بارزاً فيه، شُأنه شأن

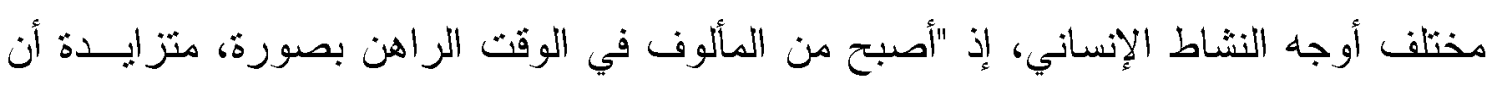
نسمع عن تفسير الحباة في عصرنا الحالي من خلال مفهوم الاغتراب"(").

حاول فناني المهجر العراقيين رصد حركة المجنمع العراقي ، كل" وفق رؤيته ومفهومه

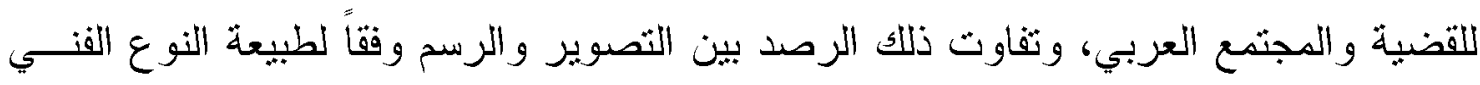

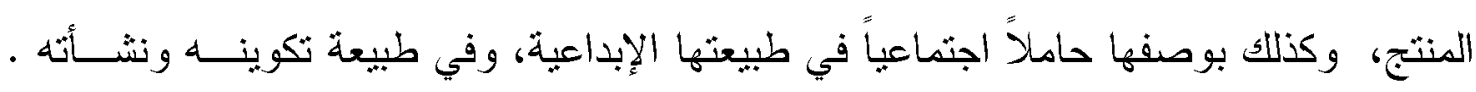
(فجاءت المنتجات الفنية غنية مغرية بالاكتثاف و التحليل، تعكس الجوانب الاغنر ايبة في نكوين 
تلك الثخصيات وفق نوع الظاهرة الاغترابية التي وسمت الفنان فحالة الاغتراب فــي أعمــال فناني المهجر العر اقيين أخذت صوراً متعددة، منها الغربة الذاتية والفكرية والنفسية، ولم تقتصر على شخصية بعينها، بل هي سمة مشتركة في النماذج جميعها"(')

ومن خلال ماتقدم نجد ان الانسان قد يدفعه اغترابه الى اللجو ـلعدة وسائل للتظلب على

الثعور بالغربة ومن جملة نلك الوسائل "المعرفة و الحياة الجنسية والحب والصداقة والحياة الاجنماعبة والإعمال الأخلاقية والفنون"(r). الفنون هي وسبلة من الوسائل المهمة الني يعبر بها الفرد عن غربته وعلى حد سواء كان انعكاس الاغتراب في الفن على الرجل و المراة واضح في منتج كلبهما وفي فن التصوير في العر اق كان للمراة دور ا مها من خلال ماقدمثه من منتج فني اثرى فن التصوير لفناني المهز العر اقيين بصورة خاصة وللفنانيين العراقيين بصورة خاصة ومن جملة ثلك الاسماء النسوية العراقية في المهجر نلك الاسماء ظهرت لنا ثلاث فنانات في مجال التصوير :

\section{إلالفنانة وداد الاورفظي :}

ولدت في بغداد سنة 949 ا. درست الفن والخدمة الاجنماعبة في الجونير كوليج في بيروت غادرت العراق ملتحقة بزوجها وتنقلت بين عدد من الدول و العواصم، ألمانبا ونيويورك بكري وباريس وعمان و إسبانيا والسودان وتونس ولندن.بعد عودنها للعراق من أفتتحت قاعة خاصة في عام س1911 م وهي قاعة الأورفلي للفنون. ولقد اصبح ذلك صرحا احتضن كافه أنواع بـن الفنون، الذي أضاف بعدا خاصا للواقع الفني العر اقي على مدى عشرين عاما.حيث كانت ثلاك القاعة مركزا نقافيا جامعا؛ فإلى جانب عرض كل أنواع الفنون التشكيلية كانت هنالك

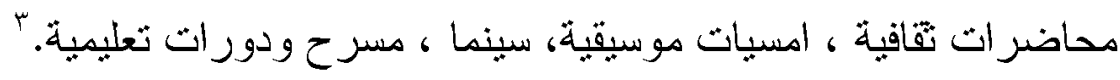

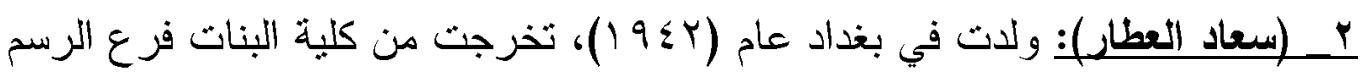

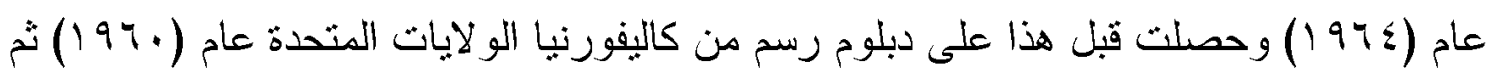

(1) الحس الاغتر ابي في أعمال روائية لغسان كنفاني الدكتورة مريم جبر فريحاتمجلة جامعة دمشق ـ المجلد بr ـ العدد الثالث+الر ابع r

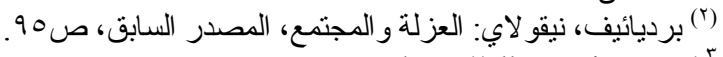
http://albayaniq.com/ ${ }^{r}$ 
أندت دراسة الاختصاص العالي في الحفر (الكر افيك) لمدة خمس سنوات في لندن. أول

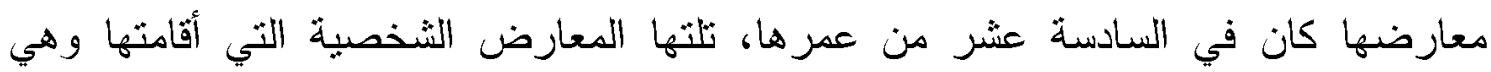

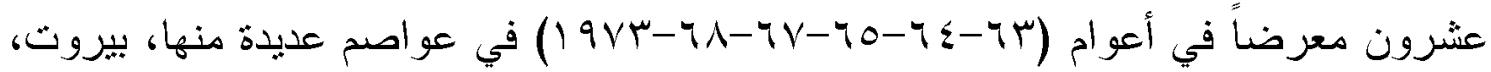

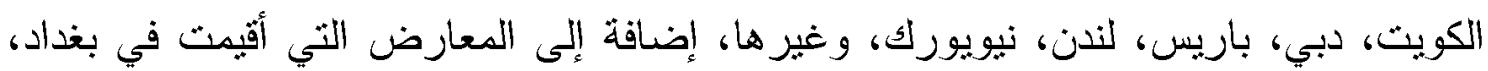

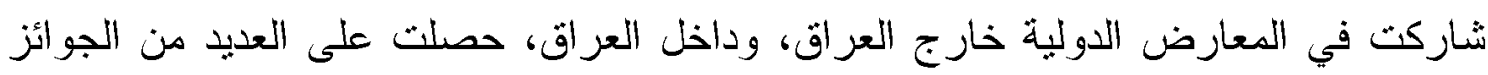

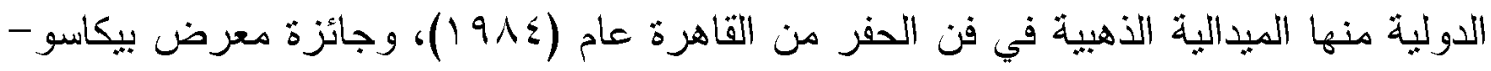

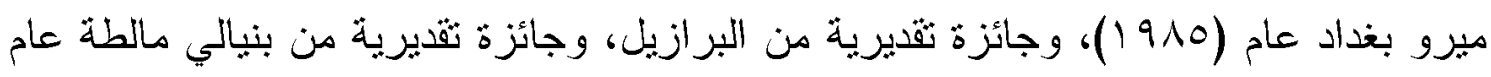

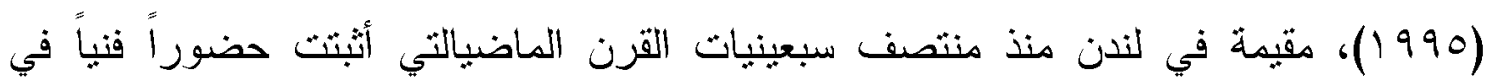
الحركة التثكيلية المعاصرة في العراق، واكتسبت أهمية خاصة من خلال موقفها مع الإنسان،

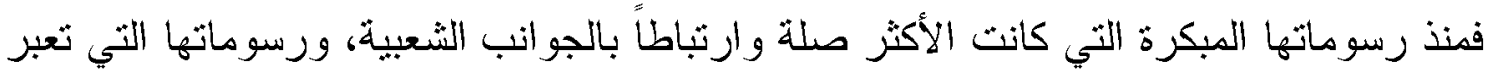

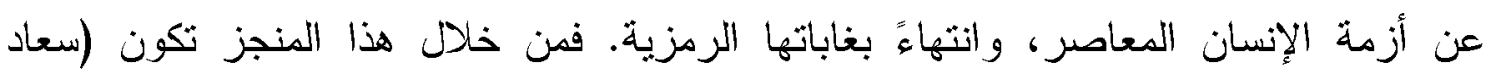

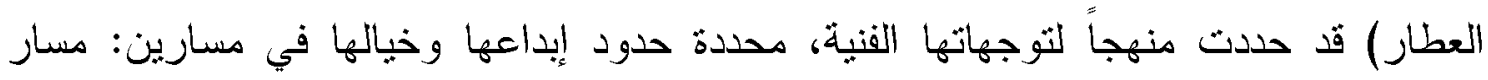

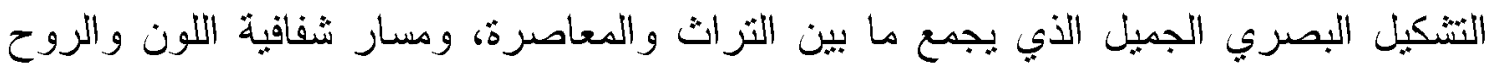

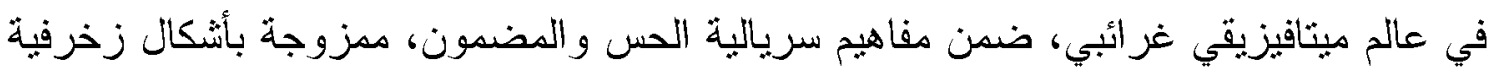

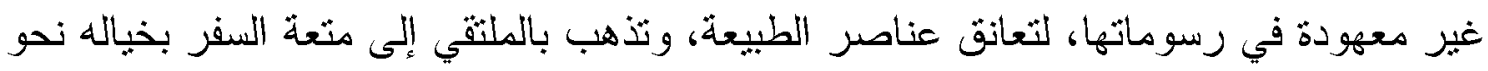

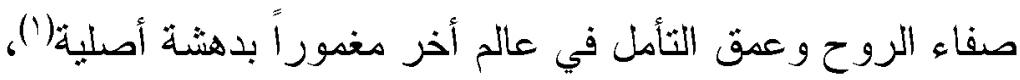

بـالفنانة (عفيفة لعيب): ولدت في البصرة عام (1904) درست الرسم في معهد الفنون الجميلة ببغداد وتخرجت منه عام (9V々 (19) ودرست في معهذ سوريكوف للفنون الجميلة

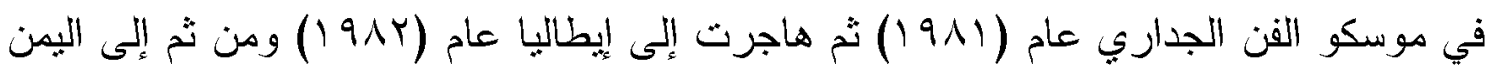

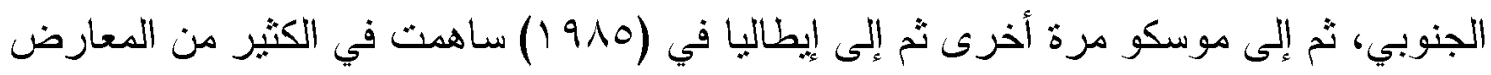

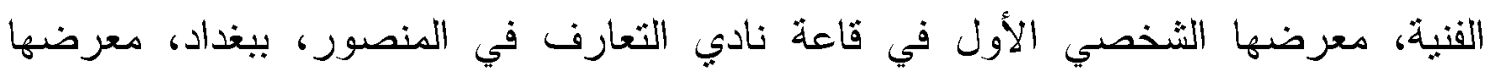

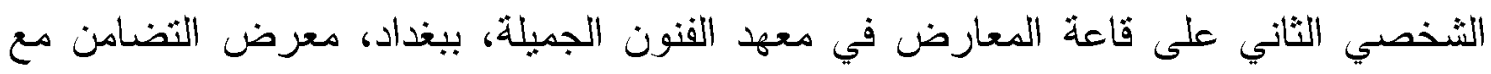

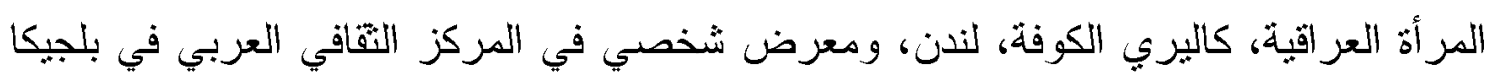

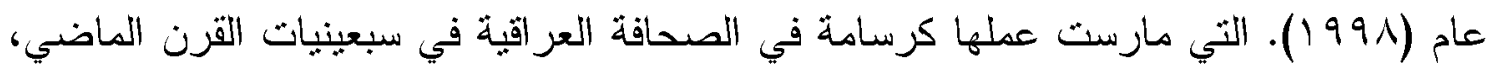
قبل هجرتها من العراق إلى المهجر الأوربي الذي عاشت وعملت فئ فيه لأكثر من خمس وثنالثين

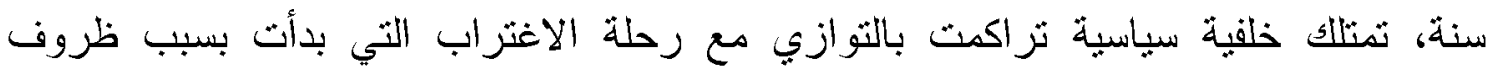

$$
\text { (1) عبد المجيد، أكتم: الفنانة سعاد العطار (الصرخة الفنية العر اقية في وجه الحرب) شبكة الانترنيت موقع فكر . }
$$


سياسية منذ سن الحادية والعشرين، عندما تركت البصرة(1). فتنقلت من بلد إلى بلد وتعايثت مع تقافات ولغات مختلفة أغنى تجربتها الفنية

\section{مؤشرات الإطار النظري}

أ_جاء تصوير الفنانات العر اقيات في المهجر معبّر بشّكل واضح عن طييعة الأحداث السباسية الني يمر بها النُعب العربي والثتعب العراقي على وجه الخصوص .

r_حمل التصوير العر اقي للفنانات العر اقيات في المهجر بذرة التحولات الأسلوبية والتـــردات التي تعي طبيعة المرحلة التي يمر بها العراق و العالم.

rـحمل التصوير العر اقي للمغتربات طبيعته الذانبة للتعبير عن الموضوع لكثف ذات الإنســان وذات الآخر في الوقت نفسه داخل روئية فنية جديدة.

؛_حمل التصوير العر اقي في المهجر (الفكر) بوصفه كائناً بين الثاريخ والجغر افية.

ه_عبّر التصوير العر اقي في المهجر عن الشعور بالوحدة (الاغتراب)، حيث أمضــى حباتــهـ

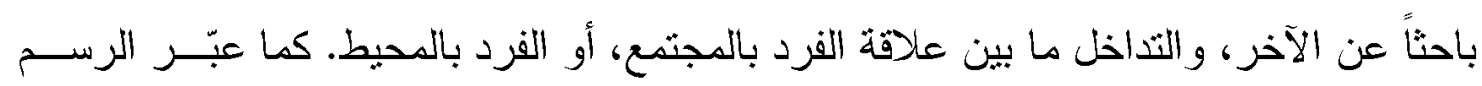

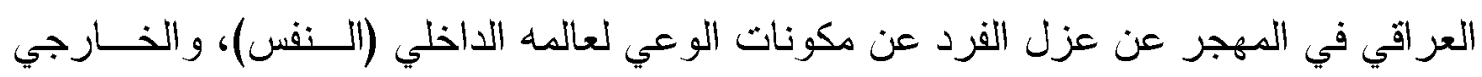
(الفيزيقي). أ_العينات : (1) - n

$$
\begin{aligned}
& \text { 1-وداد الاروفلي مو اليد (9 } 9 \text { (م) } \\
& \text { Y-سعاد العطار موالبد (Y؟9 (م) } \\
& \text { r- عفيفه لعيبي مواليد (Y0 (90م) }
\end{aligned}
$$

(1) فائق، فينوس: حوار مع الفنانة عفيفة لعيبي: عفيفة لعيبي: لم أنقطع يومأ واحدأ عن العراق، موقع الحوار الدتمدن، شبكة الانترنيت، http://www.alhewar.org/debat.Show.art.asp?aid=126292\# 
ب_ استند اباحث الى مااسفر عنه الاطار النظري من مؤثرات ا في التحليل

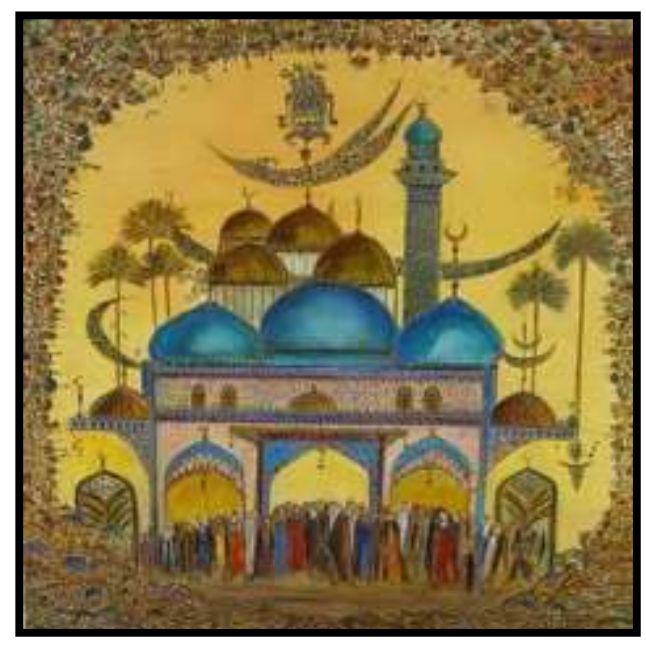

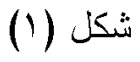

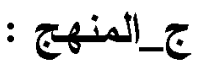 \\ اتبع الباحث المنهج الوصفي في تحليل العبنات. \\ د_تحليل العينات :

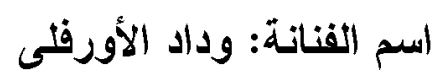 \\ اسم اللوحة: الئيات رمضانية \\ الوصف و التحليل :
}

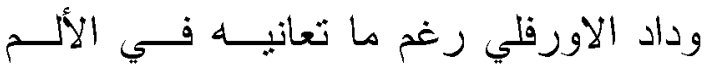

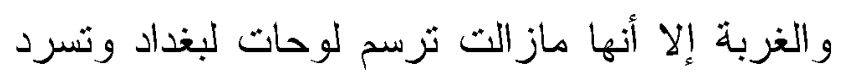

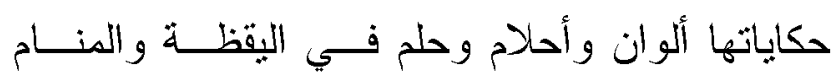
ير اودها بأن تعود الطيور إلى أعشانشها

الفنانة وداد الأورفلى ، لوحة جماليات

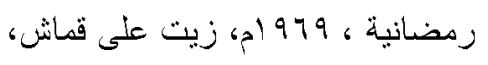

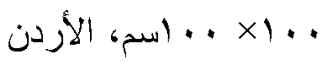

في يوم ما نتاولت الفنانة وبإحساس أرابيسكى متتاغم، ونالف بين المنمنــات الإســلامية

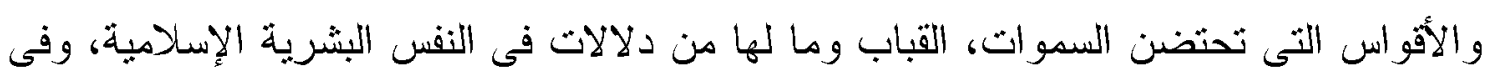

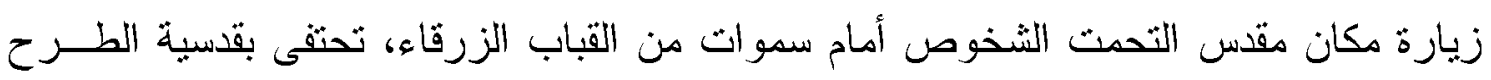

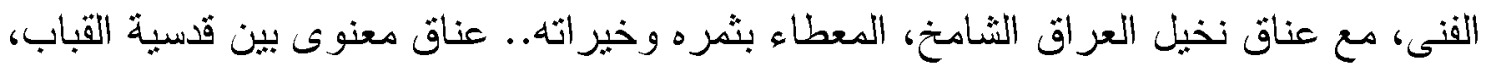

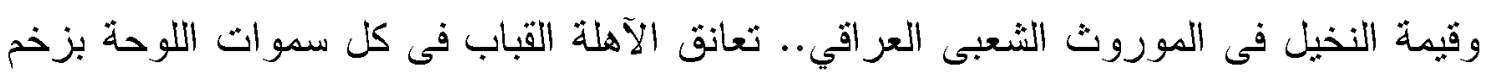

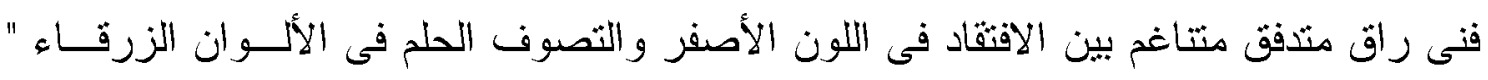

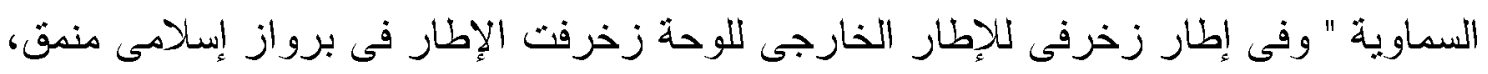

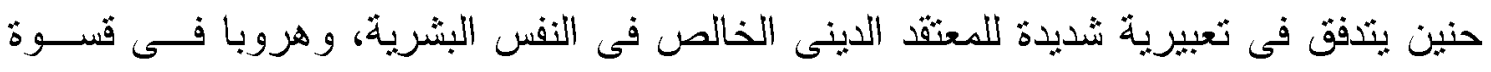

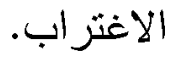

جعلت الفنانة من الأقواس النصف دائرية "القباب" مع إلتقاء الخط الرأسي للمأذنة ، والمســنطيل

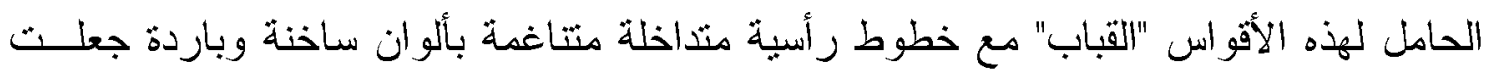
منها شخوصاً تطون حول هذا المقام لأحد العازفين باله، أو لطائفة

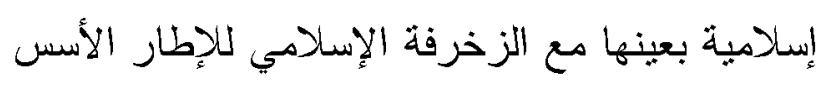
للوحة جعلت منها منمنمة إسلامية مدهنة. 
والاغتراب في العمل ناتج من تدفق الحنين الثديد للمعتقد الديني وروية القصــص التأريخيــة

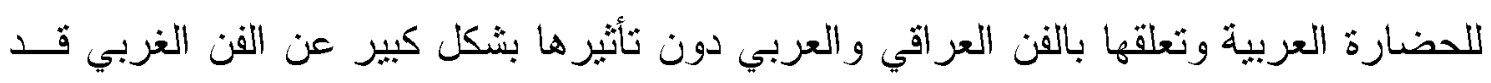

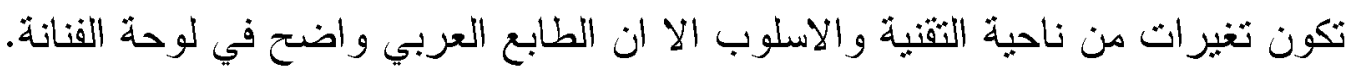

\section{اسم الفنانة: عفيفه لعيبى \\ اسم اللوحة : الصمت \\ الوصف و التحليل :}

العمل بتتاول فتاه نتظر للأمام وتستند إلي جدار وتبسط ذراعاها للأسفل ، و إلي جوارها

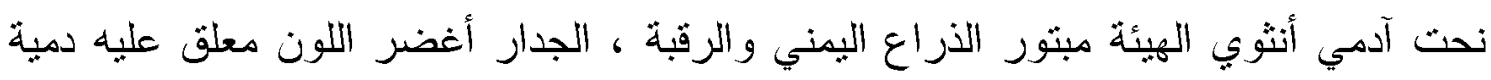

علي هيئة ملاك مجنح، وتوجد بمحاذاته من الجهة الأخري إطار معلق عليه آلة نفخ موسيقية. الفتاه تنظر نظرة سرمدية خالدة كتلك التي ترنسم علي وجوه المنحوثات المصرية

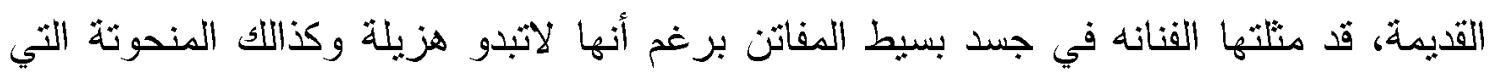

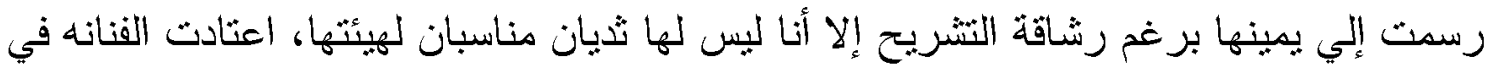

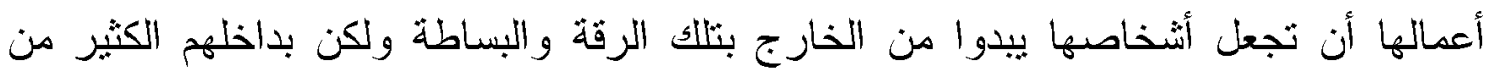

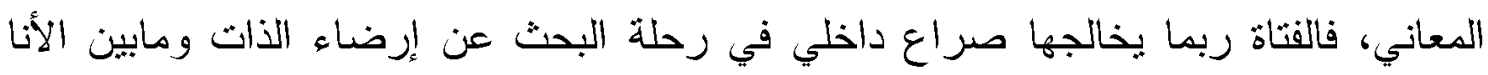

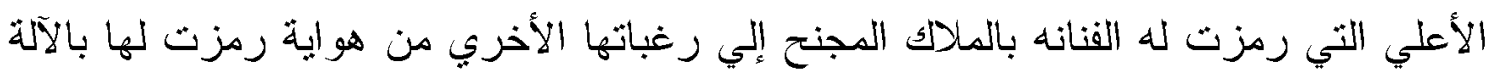

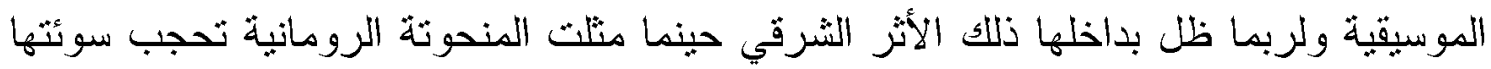

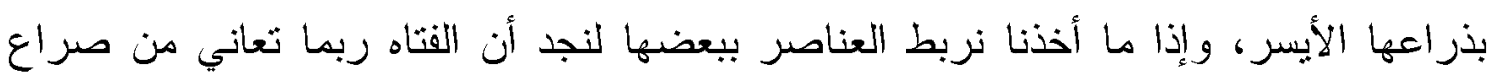

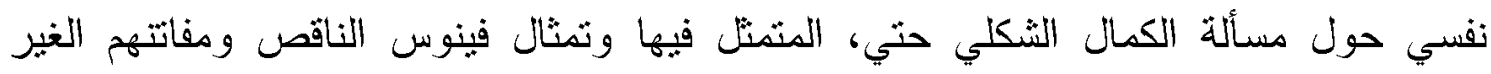

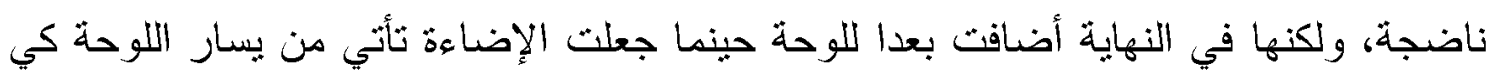
ترمز بها لأثر الييئة عليها والغربة التي رمت عليها ظلانلا قد صورتها في ظلال مائلة ليبدوا

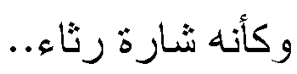

الفنانه اتخذت من الطراز الغربي رشاقة الخطوط والتعبيرات الكلاسيكية الخالدة بالإضافة للجموعة اللونية ولكنها أخذت من الثرق المضمون الفكري من القضية الثي تحملها الفناة بذهنها و القضية التي نتبناها اللوحة بشكل عام من قضايا المر أة التشرقية. 


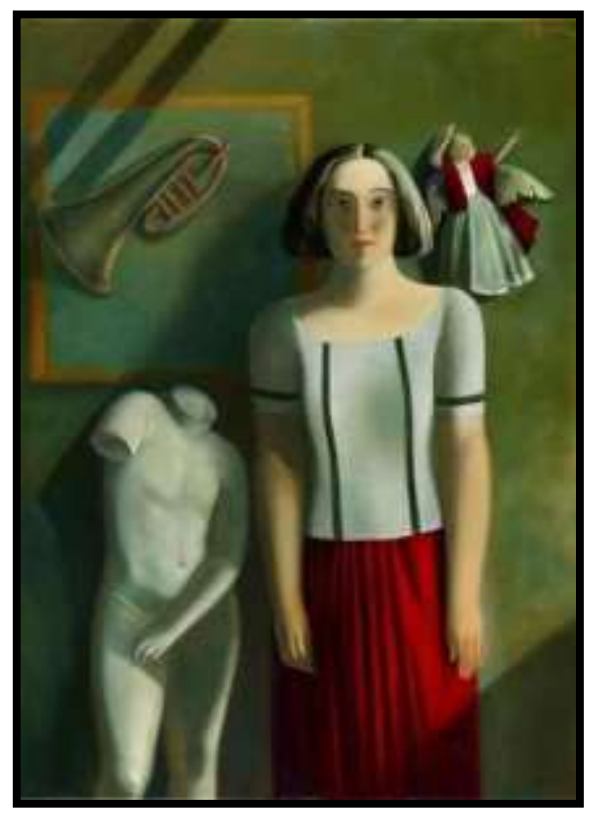

(Y) شكل (Y)

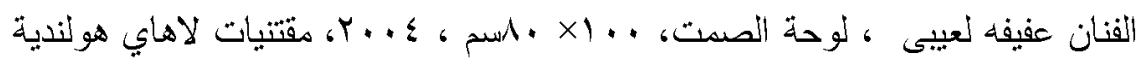

اسم الفنان : سعاد العطار اسم اللوحة : التوصف والتحليل :

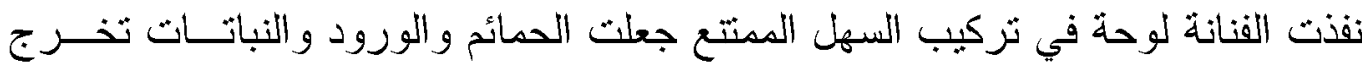
علينا في نصف قوس دائرة وكأنه هلال لم يكتمل ويخرج منه بعض الحمامة والاخر ينأمل فـي الناحية البسرى من اللوحة ، وجعلت من سماء اللوحة عناصر من المفردات التشكيلية المنفــردة بها و على يمين اللوحة رسمت البراق "الحصـان المجنح" الذى يحمل رأس انسان و هي مزاوجــة يين الحضـار ات والاشورية و اليونانية والاكدية، حصان مجنح وفي خلفية قمر كامسلـل وبجــواره هلال مع اضافة اللون القاتم في سماء اللوحة لتؤكد عناصر ها التشكيلية. وفي الخط الارض للوحة رسمث البيوث البسيطة والمتعانقة بجوار البعض وهي تحمل الحنين الى دفه الوطن، وبهجة الاخضرار في نخيل العراق.

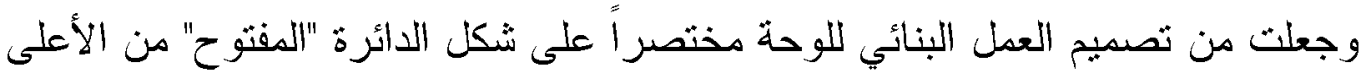

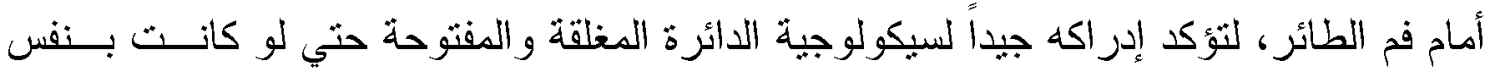

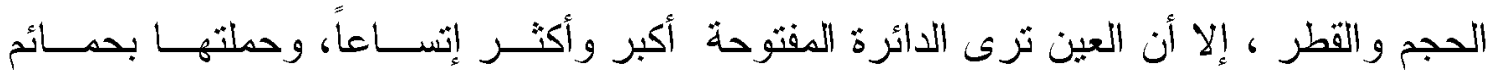
وطيور، مع نزديد وتتاغم بين فكرة الطيران بين الطائر والحيوان، ورسمت في سماء اللوحسـة

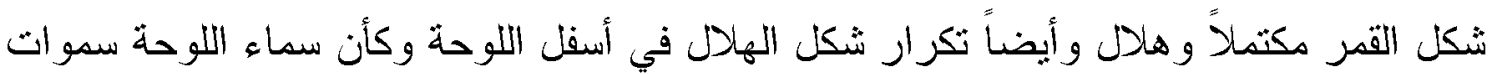


مختلفة ومتكاملة متتاغمة.ومن خلال العمل وتككوين العناصر واستخدام الالـــوان القاتـــة فــي

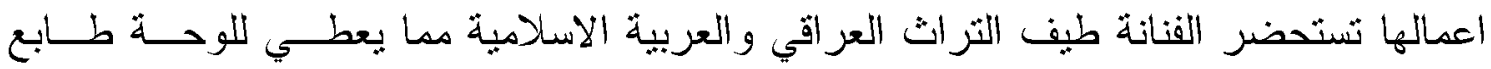
ماضويا لرمزية الخر افة والاسطورة

و هذ مايدل تعمقها بالحضارة العر اقية وتمسكها بأصالتها و الحفاظ على هويتها .

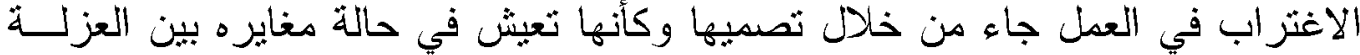

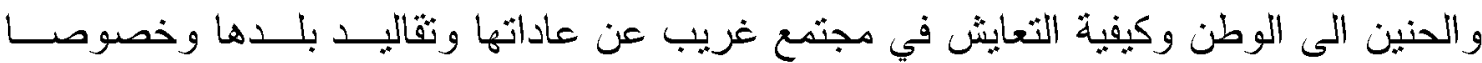

الفنانات المغتربات

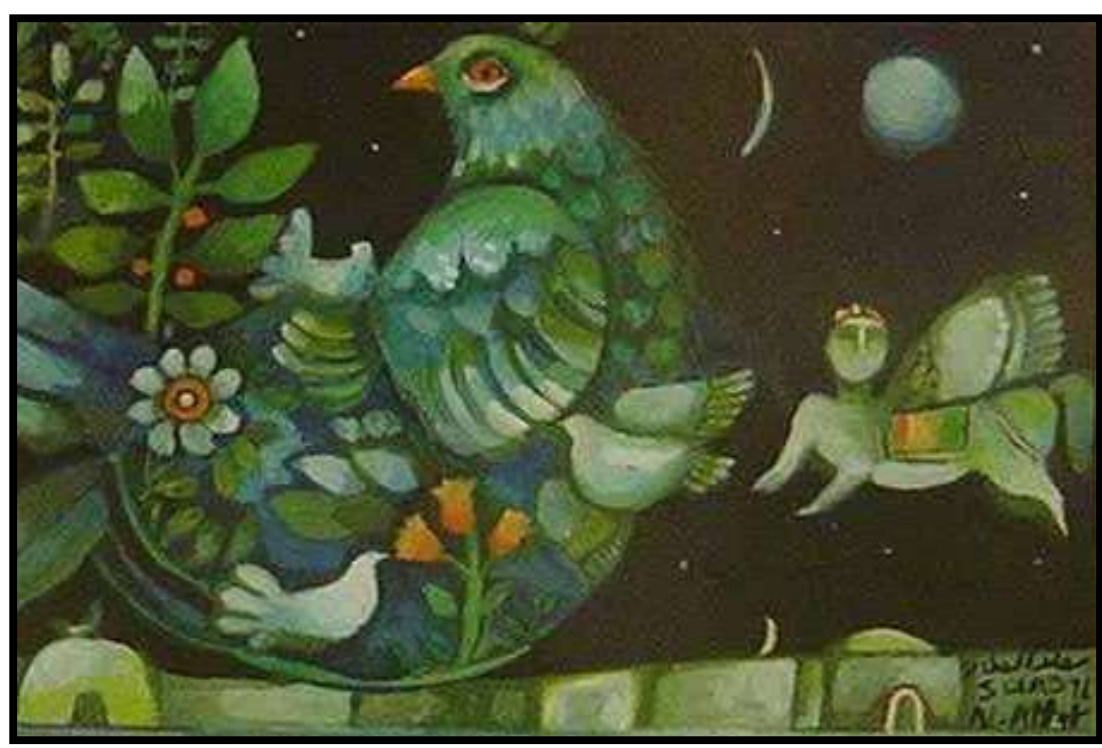

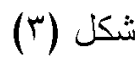

الفنانة سعاد العطار ، ب991م ، زيت على قماش ، لندن 
ا- ظهرث في التصوير العراقي للفنانات العراقيات في المهجر اتجاهات ونزعات أسلويية متباينة، اتخذت سمات شكلية تجريدية وشبه تجريدية، وو اقعبة تقريريــة، ، و الخبــرات الذاتية التي أعطت الأهمية للأثز البيئي (المحبطي).

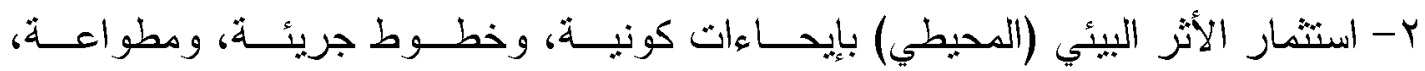
ومنشابكة، ذات نزعة تفكيكية، لنظهر الخطوط والألوان بحركة دائبة، نتيجــة الإيقة عـاع الذي خلّنته الأشكال المتشابكة.

ب- العمل على تحويل مفهوم اللاوعي إلى رموز مُكثّة نتثل وفق آلبة عفوية إلى طقولــة

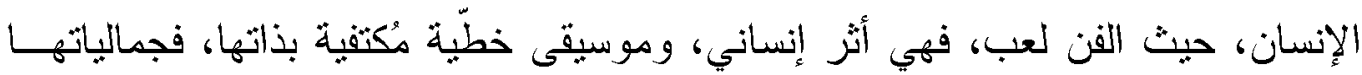
تكون وفق هذه المعادلة، الحياة والذكريات مرة واحدة في سطح تصويري واحد. ع - الكثف عن عمق المحرّكات الإنسانبة والصراع الذي بعيثـه الإنسان المعاصروخاصــة المراة العراقية وفق للظروف التي تعايشت معها الفنانات قبل وبعد الهجرة. التوصيات : - التو

في ضوء ما اسفر عنه البحث من نثائج يوصي الباحث بما بأني: ا. الاهنمام بالفن العراقي في المهجر و التاكيد على اهميته في مواكبــة العالمبــة بايجابيــة

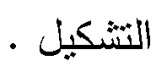
Y. الافادة من البحث الحالي في معرفة الابعاد الفكرية والجمالبة لفن الرسم والثصوير فـي المهجر

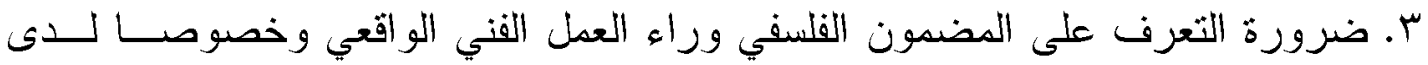
العنصر النسوي الأي بشكل اهية لاثقل عن اهمية العنصر الأكري . 


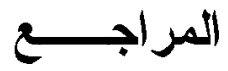

1. أبو عيانه، فتحي محدد: جغر افية السكان، دار النهضة العربية، بيروت، .... ب. r. توفيق الجرجور، ، الهجرة من الريف إلى المدن في القطر العربي السوري، منشورات. وزارة الثقافة، دمشق، . 191.

r. خليل ، سمير كاظم : ماذا حققت الواقعية الاتشتر اكية بعد أكثر من نصف قرن ، جريدة

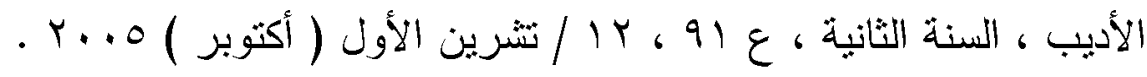

ع. دراج ، فيصل ، الاغتراب الموسوعة الفلسفية العربية ، طا ، مج ا ل، (بيروت : معهد الاتحاد العربي ، 1919 (1).

ه. الديب، محمد محمود إبراهيم: الجغر افية السياسبة، منظور عام، مكتبة الأنجلو المصرية،

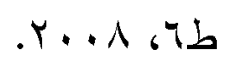

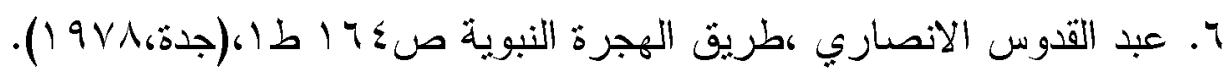

V. عبد المنعم ، مجاهد ، الإنسان و الاغثراب ، ط ا ، ( دمثقق : ســـد الــدين للطباعـة

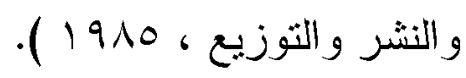

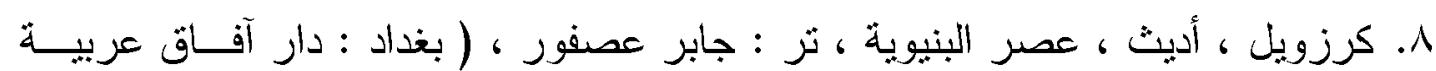

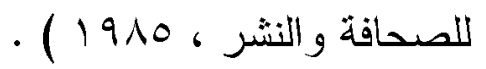
9. المنجدفي اللغة والإعلام ، طن ، ( بيروت : معاجم دار المشرق ، ب1911 ) . • 1. نابلسي، محمد سعيد - علم السكان، منشورات جامعة دمثق 1919. 11. ويكيبيديا: الموسوعة الحرة، الهجرة، شبكة الانترنيت، الرابط: www.wewkibedia.com 


\section{ملخص البحث}

تضمن هذا البحث دراسة عن فن التصوير لدى الفنانات العر اقيات في المهجر وســلط الضـــوء

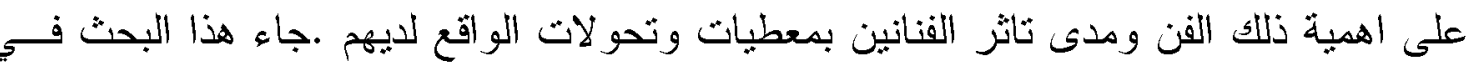

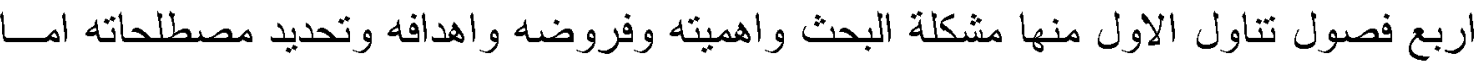
الفصل الثاني وهو الاطار النظري فجاء على مبحثين الاول تتاول الهجرة واســابها و المبحــث الثاني تتاول الاغثراب في الفن.اما نحليل العينات فجاء في المبحث الثالث وثتاول الباحث ثلاث عينات للتحليل لفنانات مغتربات وهن وداد الاورفلي عفيفة اسكندر وسعاد عطار ومن ثم النتائج

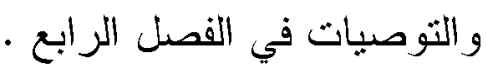

\section{Research Summary}

This research included a study of the art of photography with artists Iraqi diaspora and highlighted the importance of this art and the vulnerability of artists with data and shifts actually have .jae this research in four chapters I dealt with them the research problem and its significance and homework, objectives and determine the terminology Chapter II, a theoretical framework came on two sections first address migration and causes the second topic dealt with alienation and understandable psychological and philosophical. As the analysis of samples came in the third section and the researcher three samples for analysis of the artists Mgterpat weakness and Dad Orfali chaste Iskandar and Suad Attar and then the findings and recommendations in the fourth quarter. 